\title{
To examine the cost and returns of cotton under contract and non-contract farming situations
}

See end of the paper for authors' affiliations

Correspondence to : V.S. MASKE

Department of Agricultural Economics, College of Agriculture, Vasantrao Naik

Marathwada Krishi

Vidyapeeth, PARBHANI (M.S.) INDIA

Paper History :

Received : 16.02.2015;

Revised : 01.07.2015

Accepted : 30.07 .2015
ABSTRaCt : Parbhani and Beed districts were purposely selected because the districts were taking contract farming in cotton crop, from two districts two tehsil were selected. Each tehsil ten villages were selected on the basis of highest area under contract. Ten farmers were selected randomly from each village for contract farming and same procedure was adopted for non-contact farming in case of cotton crop. The total effective sample size of respondents were 200. In case of contract farming, use of hired human labour was 130.04 man day, family labour 23.59 man day, bullock labour 22.27 pair day, machine labour 5.75 hours, seed $1.79 \mathrm{~kg}$, nitrogen $140.07 \mathrm{~kg}$, phosphorus $60.30 \mathrm{~kg}$, potassium $89.74 \mathrm{~kg}$, micronutrient $53.86 \mathrm{~kg}$ in that magnesium sulphate, borax and zinc sulphate was used, manure 42.23 quintal, plant protection 2.14 lit. Main produce was 17.44 quintal while by produce was 35.04 quintal. In case of non-contract farming use of hired human labour was 131.16 man day, female labour $29.14 \mathrm{~kg}$, bullock labour 26.2 pair day, machine labour 4.09 hours, seed $1.31 \mathrm{~kg}$, nitrogen $124.51 \mathrm{~kg}$, phosphorus $63.62 \mathrm{~kg}$, potassium $83.44 \mathrm{~kg}$, micronutrient $11.25 \mathrm{~kg}$ in that use only magnesium sulphate, manure 28.47 quintal and plant protection 2.01 lit. Then main produce and by produce was 13.22 quintal and 21.04 quintal. It was observed that, in cotton production under contract farming rental value of land $(22.05 \%)$, hired human labour $(16.85 \%)$, fertilizers $(9.90 \%)$ bullock labour $(8.92 \%)$, seed $(7.92 \%)$ under non-contract farming major item was hired human labour (20.47\%), rental value of land (17.49 $\%$ ), bullock labour (11.74\%), fertilizers ( $10.65 \%)$, seed (6.53\%) were major items of expenditure. Gross return was Rs. 49718.56 and Rs. 35312.4 under contract and non-contract farming. In which contract farming main produce was Rs. 47616 and by produce was Rs. 2102.56, in case of non-contract farming main produce was Rs. 34050 and by produce was Rs. 1262.4 per hectare. In cost of cultivation total cost was Rs. 37440.99 and Rs. 33470.52 in contract and non-contract farming. The net profit was Rs. 12277.57 and Rs. 1841.88 regarding contract and non-contract farming. Then the benefit: cost ratio over total cost was 1.33 and 1.05 in case of contract and non-contract farming.

KeY Words : Cost, Returns, Contract, Non-contract farming

How To Cite This PAper : Maske, V.S. and Chavan, R.V. (2015). To examine the cost and returns of cotton under contract and non-contract farming situations. Internat. Res. J. Agric. Eco. \& Stat., 6 (2) : 321-324. 